\title{
RECONCEPTUALIZATION OF INDONESIA LAW SUBSTANCES
}

\author{
Prasetijo Riyadi ${ }^{1}$ and Sri Priyati ${ }^{2}$ \\ ${ }^{1}$ Professor in Law of Law Faculty Bhayangkara University, Surabaya \\ ${ }^{2}$ Associate Professor in Law of Law Faculty Bhayangkara University, Surabaya \\ Email: yullianae@gmail.com
}

Submitted: 2017-04-12 | Accept: 2017-08-29

\begin{abstract}
Law is designed to bring justice to the people and to establish good public order. The idea of rule of law construction encouraged fundamental changes to the rule of law itself in accordance with country's values and interests. This article focuses on what exactly the substance of law and examines how such substance is understood by society. Furthermore, it analyses the application of such substance of law within the society and government organization. It further intends to enable articulating and emphasizing the law and its actual application in "the wholeness" and "helix"

Re-conceptualization of conductive-correlative law substances to the understanding and meaning of the law as a norm that has social moment is necessary. The urgency to reconsider the construction of law substances is encouraged by the real fact, which law has deceived into supporting the power abuse, corruption, collusion and nepotism.

This research argues that law is not just a normative abstraction, but also in its form as the totality of empirical phenomena that exist in social entities. Law should be understood in the sense of a dynamic, not static, and not general from the juridical elements. In the reformation era, only conceptual understanding that has the relevance.
\end{abstract}

Keywords: law substance, power

\section{INTRODUCTION}

Discussion to reconsider the concept of Indonesia's law substances, reminiscent of the Satjipto Rahardjo's idea, in a paper entitled "Rekonstruksi Pemikiran Hukum di Era Reformasi”. He has critically explained that law position which oriented to the establishment of a law system is completely capable "to bring justice, to the people". 1

\footnotetext{
${ }^{1}$ Satjipto Rahardjo, 'Rekonstruksi Pemikiran Hukum Di Era Reformasi', (Paper presented at National Seminar Menggugat Pemikiran Hukum Positivistik Di Era Reformasi, Semarang 22 Juli 2000).
}

DOI: http://dx.doi.org/10.21776/ub.blj.2017.004.02.03
The above idea gives hopes to encourage fundamental changes to the rule of laws in accordance with country's values and interests. The need to re-concept law substances: from the arrangements which inclined to authorities toward the rule of law that is in line with the society interest, it is essentially a natural demand in deconstructing formalistic towards empirical.

The separation of the two law concepts, namely the formalistic normatic 
and empirical sociological reflects the dynamic development of law. This development is likely to be realized and discoursed by I.S. Susanto and Bernard L. Tanya who stated as follow: ${ }^{2}$

"Each of us wander in law concept, we will soon feel and face a permanent crisis. On the one hand, we feel "safe" and "definitive" to face the principles, doctrines, and rules which are clear, rigid, and systematic. However, we will falter immediately when facing the relevance or social significance problems of all the normative arrangement. Is "normative schemes" quite representative to describe the human reality that to be arranged."

Fundamental thought of Boaventura de Sousa Santos in his book entitled "Toward a New Command Sense: Law, Science and Politics in the Paradigmatic Transition", discussing the arguments of realism and ethnocentrism, it is a conceptual framework that shows law modernity. Through argument commensurate with the interpretation of community, law must be understood over a dynamic scope which needs persuasive argument by using logic scientific thought. ${ }^{3}$ Likewise as stated by A.H. de Wild that "the law is not autonomy rule". "Such rationale clearly reflects the reconceptualization of law substance. As

\footnotetext{
${ }^{2}$ I.S. Susanto dan Bernard L. Tanya, Wajah Hukum Di Era Reformasi (Kumpulan karya Ilmiah Menyambut 70 Tahun Prof. Dr. Satjipto Rahardjo), (Bandung: Citra Bakti, 2000).

${ }^{3}$ Boanventura de Sousa Santos, Toward a New Common Sence: Law Science and Politics in the Paradigmatic Transition, (New York: Routledge, 1995).

${ }^{4}$ A.H. de Wild, 'Pendidikan Hukum Antara Ilmu dan Profesi, Pro Justitia', (1994) XII 1 Pro Justisia.

complex rules ${ }^{5}$, the law is not a neutral phenomenon. Laws are in a tangle of problems and society dynamics ${ }^{6}$. Legal and social phenomena are put on the same level. In an atmosphere of law, "Sein" and "sollen" can not be separated. The law is the ambiance of das sein in which contain das sollen to get his form. In law, the facts and the rules are always running coincidentally: the law is the facts and rules as well ${ }^{7}$. Law have not been known and understood by highlighting the ideal rules that are considered as a reflection of the law. ${ }^{8}$ Friedrich Karl von Savigny, figures of history sect stated: “... That law can not be understood without an appreciation of the social milieu in which it has development"9.

Considering "Gesert ist Gesert" ansich, regardless of practical realm and diversity dimensions, is a fragile ${ }^{10}$ optical arrogance and denying "the relationship of law and society". The study of "the law is the law" is an extreme product of the normative reduction attitude towards the law, and culturally. Law has been cleared

${ }^{5}$ O. Notohamidjojo, Demi Keadilan dan Kemanusiaan: Beberapa bab dan Filsafat Hukum, (Jakarta: BPK Gunung Mulia, 1975).

${ }^{6}$ Hermin Hadiati Koeswadji, Korupsi Di Indonesia Dari Delik Jabatan ke Tindak Pidana Korupsi, (Bandung: PT Citra Aditya Bakti, 1994).

${ }^{7}$ D.H.M. Meuwisen, 'Pengembangan Hukum', (1994), XII (1), Pro-Justitia.

${ }^{8}$ Hermin Hadiati Koeswadji, Beberapa Permasalahan Hukum dan Pembangunan Hukum, Hukum dan Pendidikan Hukum, dan Hukum dan Bantuan Hukum, (Surabaya: PT. Bina Ilmu, Surabaya, 1980).

${ }^{9}$ George Whitecross Paton, A Tex -Book of Jurisprudence, (Oxford: Clarendon Press, 1955).

${ }^{10}$ N.E. Algra, Pengantar Ilmu Hukum, (Bandung: Bina Cipta, 1991). 
from the non-judicial elements ${ }^{11}$. The consequences are as follow: ${ }^{12}$ "... First, strengthening the normative impression of law. Second, narrowing the appearance of laws. Third, the separation of the law norms from other law elements. Fourth, breaking the relationship between the law and reality. Fifth, narrowing the scope of jurisprudence study. Sixth, directing jurisprudence into science professionalism. Seventh, weakening the value of law axiology. Eighth, weakening the anticipation of law science to practical life.

From the background above, it's clearly proven that perspective of reconceptualization which conducivecorrelative to the understanding of the law as a norm that has social moment is significant. A description and holistic critical exploration for the law with all of its attributes. $^{13}$ Clearly, it's needed a perspective that has validity theoretical and practical.

This conceptual research is intended to enable articulating and emphasizing the law and its actual application in "the wholeness" and "helix"14. Why does Indonesian Law

\footnotetext{
${ }^{11}$ Lili Rasjidi, Filsafat Hukum, Apakah Hukum Itu, (Bandung: Remadja Karya, 1985).

${ }^{12}$ Lili Rasjidi dan L.B. Wyasa Putra, Hukum Sebagai Suatu Sistem, (Bandung: PT. Remaja Rosdakarya, 1993).

${ }^{13}$ Soerjono Soekanto, Penegakan Hukum, (Bandung: Bina Cipta, 1983).

${ }^{14}$ Adam Podgorecki dan Cristoper J. Whelan, Pendekatan Sosiologi Terhadap Hukum, (Jogja: Bina Aksara, 1987).
}

Substances still needed to be reconceptualized?

\section{LEGAL MATERIALS AND METHODS}

This research uses a normative juridical method. The legal materials of this paper are primary and secondary legal materials. It uses the statute and conceptual approaches as well as case study approaches. It begins with a brief description of Indonesian Law in reality followed by such law in place sometimes could not cope to establish a sufficient rule of law in order to reach good public order. It further followed by a proposed legal reconceptualization approach.

Basic theory and conceptual legal norm are constantly used to sharpen the analyses of the problems of law in the application in society. The finding of this research are sum up in the conclusion.

\section{RESULTS AND DISCUSSIONS}

\section{Reality of Indonesian Law}

The facts show how the law was exploited to support misleading the power, corruption, collusion and nepotism during the New Order period. This situation has brought the country to ruination. The Old Order and New Order were equally not reflecting the sovereignty vested in the 
people, even becoming increasingly authoritarian.

In New Order era, the state administration practices and its developments have endangered the law. In reformation era, there has been revealed deviations of the legislation and the weakness of laws which further proves how necessary to straighten and re-arrange the law substance. Inventory of law products ranging from constitutions, government regulations and presidential decree find ambiguity arrangements and abuse of power which affect to difficulties of implementation and enforcement of the law, as well as fostering corruption, collusion and nepotism.

In Reformation era, a portrait of law enforcement in this country has become public opinion and peaked at the end of 2009. The cases of Bibit and Chandra ${ }^{15}$, Prita Mulyasari ${ }^{16}$ and Mbah Mina are portraits of legal problems which have become public consumption and these cases were part of the judicial misguided. In addition, public attention and opinion toward law enforcement agencies is very thoughtful on the post-reformation, particularly with regard to legal issues concerning the livelihood of society, nation and state. Along with the news in the mass

\footnotetext{
${ }^{15}$ Adnan Buyung Nasution, Kontroversi Kasus Bibit Candra, dalam Prasetijo Rijadi \& Sri Priyati, Dinamika Perkembangan Teori Hukum Indonesia, (Surabaya: Putra Media Nusantara, 2012).

${ }^{16}$ See Kejanggalan Kasus Prita Menyeruak, Ibid., 125

media about public support for the law enforcement, there were also disappointments and public criticisms against law enforcement, either by the police, the prosecution or by the court. (Coins of Justice: When justices are being doit, then we also collect doit.

Society's disappointment was caused by unfulfillment of the expectations toward the process and decision's court to bring the truth, justice, peace and welfare. Until recently, most people believed that the judiciary as the last bastion to seek justice. However, the public trust is inversely related to the fact of court deterioration. Deterioration of the court against the "nature" of its existence to resolve conflicts. The court ruling only realizes the truth and the formal procedural fairness, so that substantially will never be realized. Access to justice were supposed to be evenly distributed to all levels of society can not be achieved. Thus, only the elite can enjoy it. As the implications of these circumstances, the court would be a place for mafia and market of articles.

Nowadays, law has become the most devastated institution. Its appeal as an institution for guarantor of justice is no longer visible in the realm of Indonesian's consciousness today. The reality that we often encounter is chilling: criminals who were burned alive by a mob, property destruction by the masses, the notching law 
enforcement pursued by mass and so forth, and many more.

It actually happened in the era of democratization. Consider life and law enforcement as second priority will directly paved the way for the growth and the strengthening the centralization of political power into the hands that build and produce authoritarian, dictatorial, which the actions always legitimized in the name or in the interest of the people, but the reality it is free from society control and better than the interests, the real needs of the people and of the people's sense of justice. Such actions are always packed in a written positive law suit that meets all the formal requirements of the law through the tricky engineering which subsequently upheld and enforced to be established with the support of the military personnel strength. Hence, the independence of authority and power development of effective control can cause systemically undermined for the fundamental law which resulted to crisis in the law getting worse by the massive corruption. The crisis of law and law life had reached its nadir. ${ }^{17}$

This situation seems to demand the reconceptualization of law in the society administration, politics and the state. This can only happen through a reinterpretation

\footnotetext{
${ }^{17}$ B. Arief Sidharta, Praktisi Hukum dan Perkembangan Hukum, Dalam Wajah Hukum Di Era Reformasi, Kumpulan Karya Ilmiah Menyambut 70 Tahun Prof. Dr. Satjipto Rahardjo, SH, (Bandung: Citra Aditya Bakti, 2000).
}

of law in its entirety, which is the development of law simultaneously. Francis Fukuyama, in his book The Great Disruption: Human Nature and Reconstitution of Social Order, giving his brilliant concept about the existence of a legal substance in the development of society. Law is not sufficient just viewed from the formalistic perspective. The law reduction only as a normative order that uprooted from social roots and its culture is naive. The law functional role must be reinterpreted in regards with the social needs on every level. If there is any effort to reinterpret the position and function of law in social context, then law can be confirmed for having lost its substantial meaning. This shows the necessary of the law existence which can shape the behaviour for the realization of social order.

Every society has the momentum and the pace of development in accordance with the situation and circumstances. Dynamic directions of the community reflect the social shift. Presence the information society or the information age as found in the book The Great Disruption by Francis Fukuyama, have reflected the flow of social change. In fact, the community has grown by describing the history of social order. ${ }^{18}$

The emergence of industrial society with all its character is not something

\footnotetext{
${ }^{18}$ Francis Fukuyama, The Great Disruption, Human Nature And The Reconstitution Of Social Order, (New York: The Free Press, 1999).
} 
automatic, but through the stages of economic development, social, cultural or political. The role of information on the social relationships pattern is a supporting factor that marks their social dynamics. Advances in information technology are attached to the means of communication which clearly technical shows their determination acceleration of culture between communities. Each community has and produce information in accordance with the level of its development. It is also found as well as contained in the so-called modern democracy values which include the freedom and equality. ${ }^{19}$

In reality the community move forward from agrarian to industrial structure which then leads to information arrangements. Each stage of society development has specific legal arrangement. Traditional societies have rules of traditional law and modern society is also equipped with modern rules. Of course, the information society requires informative legal rules. Through a set of rules in line with society dynamics, the law will be able to play the dynamic and functional role.

Therefore the existence of substantial law must be played in accordance with its era. Law which is born from the cultural situation of traditional societies clearly can not be applied properly in modern society that certainly has been producing modern law. Similarly, modern law can not be applied either to the informative society, because informative society have informative laws setting. ${ }^{20}$

\section{Re-conceptualization of the Law through Approach System}

Discourse of Law Study ${ }^{21}$ shows historic rotation character of the law that "empirical" and "normative" in line with the society development which, according to Henry Maine move evolutionary from the traditional type to modern type, ${ }^{22}$ and "the movement of the progressive societies has hitherto been a movement from status to contract. For Max Weber, this progressivity is inevitably bringing the law rhythm that emphasizes substance to its rational and formal form. ${ }^{23}$ Such a process commonly referred to as a process towards "autonomous" law conceptions Philippe Nonet Philip Selznick ${ }^{24}$ or the "positivity of law" according to Niklas Luhmann, ${ }^{25}$ to format the behavioral patterns corresponding to normative reference on a

${ }^{20}$ Ibid.

${ }^{21}$ P. Van Dijk, Van Apeldoorn's, Inleiding Tot de Studied van Het Nederlandse Rechts, (Zwolle: W.E.J, Tjeenk Willink, 1985).

${ }^{22}$ Soetandyo Wignyosoebroto, Dari Hukum Kolonial ke Hukum Nasional, Suatu telaah Mengenai Transplantasi Hukum ke Negara-negara yang Tengah Berkembang khususnya Indonesia, (Paper presented at Pidato Pengukuhan Unair, 1989)

${ }^{23}$ Soetandyo Wignyosoebroto, Ibid., 2.

${ }^{24}$ Phlippe Nonet dan Philip Selznick, Law and Society in Transmition Towaed Responsive Law, (New York: Haper \& Row, 1978).

${ }^{25}$ Niklas Luhmann, A. Sosiological Theory of Law, (London: Routledge \& Kagen Paul, 1985). 
Laura Nader's view: in the same breath with "the rule sound of positive law"26

What is meant by positive law, J.J.H. Bruggink wrote ${ }^{27}$ : “Onder de positiviteit van een rechtsnorm verstaat men bevoegde rechtautoriteitenvastgesteld door het zijn van de rechtsnorm in enn rechtsregel Die wordt een rechtsregel and positiefrechttelijke regal, genoemd. Positief recht van het is de vertailing fatijnse "ius positum" gesteld recht. Positief recht dat is dus het recht door mensen is vastgesteld, vandaar ook de ouderweste uitdrukking Stelling recht. (Positive law is the ius positum, translation of the Latin language, which lierally means "applied law" (gesterld recht). Thus, positive law is the law established by man, because it was in the old expression called "Stelling recht".

It means a rule must be iustum as positive, what is the state recognized as legal.State creates law with norms, govern something, ${ }^{28}$ code of conduct, ${ }^{29}$ which is sociologically often utilized as control instruments: ${ }^{30}$ Law is governmental Social Control.

\footnotetext{
26 Ibid.

${ }^{27}$ J.J.H. Bruggink, Rechtsreflecties, Grondbegrippen uit de rechtstheorie, (Netherlands: KluwerDeventer, 1993).

${ }^{28}$ Karel F.M. Bongenaar, 'Aturan adalah Norma, Beberapa aspek mengenai sifat normatif dari Peraturan Perundang-undangan', (1993) VII 1 Yuridika.

${ }^{29}$ Philipus M. Hadjon, Pengkajian Ilmu Hukum Dogmatik (Normatif), (1994) IX 6 Yuridika.

${ }^{30}$ Donald Black, The Behavior of Law, (London: Academic Press, 1976).
}

How central existence of positive law can be seen from the diversity of law knowledge that makes the object study. Dogmatic law science. Includes "alle wetenschappelijke activiteiten samengevat, welke erop Gericht zijn de inhoud van een concrete positive rechtsonde te besturderen" (all scientific activities geared to learn this from a concrete positive law), which wrap ourself in five tasks: "het beshrijven, analyseren, systematiseren, interpreteren en waarderen van (eenbepaald onderdeel) het positieve recht "31(expose, analyze, systematize, interpret and assess (a part of) the positive law. legal science empirical proposition: the" het positieve recht is een vorm van waarneembaar menselijk gedrag "(positive law as a social fact, viewed as other social facts other. Law is a form of human behavior that can be enjoyed) and ${ }^{32}$

Het is nu de taak van de (empirische) rechtswetenschap diet feit niet allen te beschrijven, maar ook met behulp van hypotheses en wetmatigheden te verklaren. Dit verklaren kan in tweerlei zin worden verstaan. Aan de ene kant kunnen sociale feiten (in ruime zin genomen) worden verklaard met behulp van het recht. Bijv ledereen rijdt rechts omdat er rechtsregels gelden, iedereen betaalt belasting omdat een bepaalde wetgeving geldt. Aan de andere kant kunnen de rechtsnormen (verschijnselen) worden verklaard met

\footnotetext{
${ }^{31}$ Ibid., 452

${ }^{32}$ Ibid.
} 
behulp van (andere) sociale feiten. Bijv Er geldt een maximumsnelheid omdat de verkeersveiligheid di zou eisen". (The task of law science (empirical) is not only exposes the fact, but also explains it through the hypotheses and constancy). It can be understood in two meanings. First, social facts (in the broad sense) can be explained through the rocks of law. For example, every person driving a vehicle on the left because there is applied rule, each person paying the tax because there is applied specific legislation. On the other hand, the rules of law (symptoms of law) can be explained through social facts (the other). For example, apply a maximum speed for traffic safety.

It is clear that the law (positive) has been a central focus of law scientific study with different perceptions and visions. Law is viewed as the norm by dogmaticnormative jurisprudence, as well as the fact of empirical law studies with a qualification "no recognized boundaries" 33 have also pointed out. "....... Science of law is a branch of disputed science by a number of other disciplines. It's started from doubts about the scientific status, until the intervention and the seizure of the study object. By describing the law as a social norm, the social sciences claims law as social sciences object (sociology of law), and through the way (law anthropology), as well as through

\footnotetext{
${ }^{33}$ I.B. Curzon, Jurisprudence, Macdonald \& Evans Ltd, 1979, V

political science. Comprehensive scientific dialog understanding is starting to clarify the context of each branch of science, but in some cases, overlapping the substance is still rather difficult to be avoided.

The dominance of the law normative reduction was more pronounced than on empirical momentum through its influence on tradition of branches knowledge in defining law. Political science describes the law as "a rule setting forth Among men either a relationship or a relationship between the state and the which is expressed, sanctioned, and enforced by state" ... the social sciences considers law: "a set of rule or norm, written or Unwritten, about right and wrong behavior, duties and rights" ${ }^{34}$ as well: ${ }^{35}$ "As the ethical control applied to communication, and to language as a form of communication, especially when this normative aspect is under control of some authority Sufficiently strong to give its decision late social sanction".

The definition only targeted laws limited to norms formulation regardless of empirical roots, thus the essence and legal capacity is not completely agonizing. The law became isolated from other nonjuridical elements which determining the presence of law in society. This normative reduction in the contemporary spectrum is

\footnotetext{
${ }^{34}$ Ibid.

35 Ibid., 28.
} 
eliminated by comprehensibly deciphering law. ${ }^{36}$

"The law in the broad sense of or whole legal system eith its institutions, rules, procedures, remedies, etc., is society attempt, through Government to control human behavior and rational, fair and workable alternatives to the indiscriminate use of force by individuals or groups in advancing or protecting Reviews their interest and resolving Reviews their controversies. Law seek to achieve both of order and individual protection, freedom and justice".

Hence, Anil Divan concludes that: "the law deals with the complexity of human life, and must be closely related to the needs of life". ${ }^{37}$

Thus, recently it is not sufficient for the jurist only capable and adept to think juridically. The jurists (bachelor of law) are demanded to be able to think scientifically in approaching and solving laws problems. 38 Manfred Rehbinder whose his opinions received by Hene van Maarseveen also anticipate the law tendency toward law inspiration. ${ }^{39}$

Mastering the law conception as the norms and the facts, each definition must be defined integrally instead of partial.

\footnotetext{
${ }^{36}$ Ibid.,

${ }^{37}$ Abdoel Gani, "Profesi Hukum: Suatu Orientasi", (1992) VII 1 Yuridika.

38 Ibid., 2-3

${ }^{39}$ Ibid.
}

Elementary and inadequate knowledge about the positive law (normative) is absolutely necessary. Only through this way, jurists can obtain through the study or research, it is possible to conduct juridical arguments in the relevance analysis facts that can be controlled and verified scientifically. ${ }^{40}$

That affirms a reflection from their suppressors for reference needs that is able to liberate the law from being merely normative and centrifugal-centripetal practical. Intrinsic expressive verbis is important to be used for an approach that is able to ascertain and describe law as a whole, namely: System Approach. Lili Rasjidi and I.B. Wyasa Putra stated:'The complexity of this problem will be very difficult to sift through an autonomous approach and therefore the systems approach in order to restore law towards its essential characteristics became clear. Along recovery, the relevant approach is important". Presumably the use of system approach in assessing the substance of the law can be understood as an option that will not be mistaken and have clear argument. What is the "system approach"?

System approach frames the object of study as "the wholeness" of a system. If the system approach is used to concept the law, logically law also accepted as a system. As a

\footnotetext{
${ }^{40}$ Gr. Van der Burt \& J.D.C. Winkelmean, "Penyelesaian Kasus, Pro Justitia", (1994) XII 1 Pro Justisia.
} 
system, the law system has also characters as follow: input, output, and feedback. ${ }^{41}$ Elegantly, Lawrence M. Friedman affirms:

"Whatever character one assigns to the legal system, it will have features common to every system or process, first, three will be inputs, raw materials which enter at one end of the system. A Court, for example, does not begin to work, unless someone makes the effort to file a complaint and set off a lawsuit. Even earlier, some concrete act has served as a trigger: A policemen arrests a man, a landlord harasses a tenant; a man is defamed by his neighbour, injured by a speeding car, deserted by his wife. Physically, lawsuit begins with pieces of paper, pleading filed in court; without these no trial is possible in our society. What happens next, the court produces an out puts a verdict or decision; sometimes the court hands down a general rule as well. The courts may dicide for the plainitiff, or for the defendant, or reach some compromise. The result is initiative event an output, even if the court simply refuses to hear the case, moreover, the output may be ignored or not, may have a large or a small effect flows back into the system. This process bears the name of feedback. One can speak of feedback more generally to mean the way product or output of a system turn back on and affects the system itself". ${ }^{2}$

Thus, the law can not be considered merely an abstract normative rule called " $d e$ wetten papieten muur. Laws must be understood against the society background in the proper definition. Various rules of law

${ }^{41}$ Ludwig von Bertalanfy, General System Theory: Foundation, Development, Application, (New York: George Braziller, 1972) ; Tatang M. Amirin, Pokok-pokok Teori Sistem, (Jakarta: Rajawali Pers, 1996), 50.

${ }^{42}$ Lawrence M. Friedman, The Legal System, A Social Science Perspective, (New York: Russel sage Foundation, 1975), 11-12. must be considered in a logical and consistent entity relationships. ${ }^{43}$ Given the law system is a system of social rules, ${ }^{44}$ with component of substance, structure and culture.

\section{CONCLUSIONS AND SUGGESTIONS}

What we have been gained? Now we must be able and willing to build a common perception that the law substance is the set of rule and norm, commonly called as the legislation (algemene verbinde voorshriften). ${ }^{45}$ In addition, the substance is composed of substantive rules about how institution should behave. The substantive rule of law is included in and outputs of a legal system. ${ }^{46}$ Within the structure framework of legal system. The legal structure related to "law enforcement". Lawrence M. Friedman stated that: The structure of a system is its skeletal framework, it is the permanent shape, the institutional body of the system, the tough, rigid bones that keep the process flowing within bounds. ${ }^{47}$

\footnotetext{
${ }^{43}$ D.H.M. Meuwissen, "Teori Hukum”, (1994) XII 2 Pro Justitia, 20.

${ }^{44}$ Saudara Ananda, H.L.A. Hart, "Pemikir Hukum Analitis”, (1995) XIII 4 Pro Justitia, 16.

${ }^{45}$ Laica Marzuki, "Sumber Daya Aparatur Hukum, (Legal Human Resources) dalam Konteks Komponen sistem Hukum", (1997) XV 4 Pro Justitia, 4.

${ }^{46}$ Ibid.

${ }^{47}$ Ibid
} 
The ideal law substance, if it's not formulated from law culture of the citizens, the law substance is merely a blueprint or a design only. The legal culture "means attitudes, values, and opinions held in society, with regard to the law, the legal system, and its various parts", ${ }^{48}$ so that culture is like "a working machine" of the legal system.

Moreover, with the different rhetoric, but the same substance Cees Schuyt argued that the law has three elements, namely: ideal elements, operational elements, and the actual elements that create a legal system. Ideal element consists of rules, norms, and principles. Operational elements are covering the entire organization and institutions, including its ambtsdrager. The actual element is the overall verdict and concrete actions related to the meaning of the legal system. So it is relevance if Berman explains broad legal definition: ${ }^{49}$

"This is the law, as some influential writers have said, is essentially a body of rules related to each other by logical consistency, than an Appropriate technique for its study is that of conceptual analysis that is, comparison of word with word, concept, According to stated criteria of reasoning. If, on the other hand, to take another definition of law is essentially an instrument of

\footnotetext{
${ }^{48}$ Setsuo Miyazawa, "Taking Kawashima Seriously, A Review Of Japanese Research on Japanese Legal Conseiousness and Dispoting Behavior", (1987) 212 Law \& Society Review, 221.

${ }^{49}$ Hadiati Koeswadji, Hukum dan Masalah Medik, (Surabaya: Airlangga University Press, Surabaya, 1984).
}

political control, then an appropriate technique for its study is of political control, then an appropriate technique for its study is of political analysis, that is a comparison of and the political consequences of alternative legal rule or a legal institution."

By understanding the law as a whole as well as its system components, intrinsic adequate for the law; The law is a fact or rule. Law has a normative nature that aims to influence human behaviour, as well as to be presented as factual data. The conceptualization of law will make the law has a dialectic nature between facts and rules, form and content. Law assessment will not be stopped in the unilateral antinomy: the form of the content, the rules of the facts, but rather try to think in a systemic relationship. D.H.M. Meuwissen pointed out:

"Het recht is nu niet eenmaal uitsluited norm of uitsluitend feit: het is beide. Van striped daarbj is het gezichtspunt van het recht bescouwet waarruit men. Maar die zijn niet gezichtspunten willekeur: er moet worden een getracht daarin bepaalde Ordering (eenhieid) te denken. Alle denken is immers op eenheid (algemeenheid) geicht '. (The law is not merely a fact: it is both). What matters to law is the point where people look at that law. However the points of view wa: in it must be cultivated to think of an arrangement (keastuan) specific. All thoughts directed towards unity (generality), doesn't it?

Reflecting the systemic aspects of the law as a whole: law viewed as a rule system or as a social fact is not disputed, but it's synergized. Law substance will acquire its 
normative meaning only from rules followed in behavior that can be seen as empirical data to be presented and explained. However, optically against and not the most extensive. This thought will be able to centralize law is not just a normative abstraction, but also in its form as the totality of empirical phenomena that exist in social entities. This way, law can be understood in the sense of a dynamic, not static, and not general from the juridical elements. In the reformation era, only conceptual understanding that has the relevance.

Satjipto Rahardjo has proper statement that: The academics and practitioners should discuss together about how the transformation can be carried out carefully. Today already afternoon to bring a legal system that is completely capable "to bring justice to the people".

\section{REFERENCES}

\section{Journal Articles}

'Profesi Hukum: Suatu Orientasi', (1992), VII 1 Yuridika, 30-47

Arief Sidharta, B., 'Implementasi Hukum

Dalam Kenyataan', (1995) XIII 3

Pro-Justitia, 25-40

De Wild, A.H., 'Pendidikan Hukum: Antara Ilmu dan Profesi', (1994) XII 1 Pro Justitia, 5-25
Hadjon, Philipus M., 'Pengkajian Ilmu Hukum Dogmatik (Normatif), (1994) IX 6 Yuridika, 28-41.

Marzuki, Laica, 'Sumber Daya Aparatur Hukum (Legal Human Resources) Dalam Konteks Komponen Sistem Hukum', (1997) XV 4 Pro Justitia, 6780.

Meuwissen, D.H.M., 'Teori Hukum', (1994) XII 2 Pro Justitia, 56-73.

\section{Books}

Algra, N.E., Pengantar Ilmu Hukum, (Bandung: Binacipta, 1991).

Amirin, Tatang M., Pokok-pokok Teori Sistem, (Jakarta: Rajawali Pers, 1996).

Bertalanffy, Ludwif Von, General System Theory, Foundation, Development, Application, (New York: George Braziller, 1973).

Black, Donald, The Behavior of Law, (New York: Academic Press, 1976).

Bruggink, J.J.H., Rechtsreflecties, Grondbegrippen uit de rechtstheorie, (Netherland: Kluwer-Deventer, 1993).

Curzon, L.B., Jurisprudence, (New York: Academic Press, 1979)

Friedman, Lawrence M., The Legal System: A Social Science Perspective, (New York: Russell Sage Foundation, 1975).

Fukuyama, Francis, The Great Disruption,Human Nature and The 
Reconstitution of Social Order, (New

York: The Free Press, 1999)

Koeswadji, Hermien Hadiati, Beberapa

Permasalahan dan Pembangunan

Hukum, Hukum dan Pendidikan

Hukum, Hukum dan Bantuan Hukum, (Surabaya: PT. Bina Ilmu, 1980).

Nonet, Philippe, \& Philip Selznick, Law and Society in Transition: Toward Responsive Law, (New Yorl: Harper \& Row, 1987).

Notohamidjojo, O., Demi Keadilan dan Kemanusiaan: Beberapa Bab dari Filsafat Hukum, (Jakarta: BPK Gunung Mulia, 1975).

Rasjidi, Lili, Filsafat Hukum Apakah Hukum Itu, (Bandung: Remadja Karya, 1985). \& I.B. Wyasa Putra, Hukum Sebagai Suatu System, (Bandung: Remaja Rosdakarya, 1993).

Santos, Boanventura de Sousa, Toward New Common Sensel Law, Science and Politics in The Paradigmatic Transsition, (New York: Routledge, 1975).

Susanto, I.S., \& Tanya, Bernard L., Wajah Hukum Di Era Reformasi (Kumpulan Karya Ilmiah Menyambut 70 Tahun Prof. Dr. Satjipto Rahardjo, SH), (Bandung: Citra Aditya Bakti, 2000).

Sawer, Geoffrey, Law in Society,(Oxford: Clarendon Pers, 1973).
Soekanto, Soerjono, Penegakan Hukum, BPHN, (Bandung: Binacipta, 1983).

Soemitro, Ronny Hanitijo, Masalahmasalah Sosiologi Hukum, (Bandung: Sinar Baru, 1983).

Arief Sidharta, Refleksi Tentang Hukum, (Bandung: Citra Aditya Bakti, 1996).

Van Dijk, P., et. Al., Van Apeldoorn's inleiding Tot de Studies van het Nederlandse Recht, W.E,J. (Zwolle: Tjeenk Willink, 1985).

\section{Papers (Unpublished and Published)}

Gani, Abdoel, Analisis Sistem; Suatu Orientasi, Kursus Dasar-dasar Analisis Mengenai Dampak Lingkungan, (Paper presented at Lemlit Uniar, Surabaya, 1986).

Rahardjo, Satjipto Rekonstruksi Pemikiran Hukum di Era Reformasi, (Paper presented at National Seminar Menggugat Pemikiran Hukum Positivistik di Era Reformasi, Semarang, 22 Juli 2000).

Wignjosoebroto, Soetandyo, Dari Hukum Kolonial ke Hukum Nasional, (Paper presented at Pidato Pengukuhan, Unair, Surabaya, 1989). 
